\title{
The Quality of Life of Hydrocephalus Children with Shunt Implants: Literature Review
}

\author{
${ }^{1 *}$ Deni Lusiana, ${ }^{2}$ Allenidekania \\ ${ }^{1,2}$ Faculty of Nursing, Universitas Indonesia, Depok, Indonesia
}

\begin{abstract}
Shunt implant on hydrocephalus children can affect their quality of life, hence, it necessitates a standard instrument to evaluate the children's quality of life. This literature study provides an effective instrument to evaluate the quality of life of hydrocephalus children with shunt Implants. The findings of this literature study reveal that 10 articles fit the inclusion and exclusion criteria. The article reviews reveal several instruments used to evaluate the quality of life of hydrocephalus children with shunt implants, namely, the HOQ, PedsQL 4.0, OHS, HRQOL, mRS and SLHS questionnaires. Based on the findings the pieces of literature can become the basis for providing and developing interventions to improve the quality of life of hydrocephalus children with shunt implants.
\end{abstract}

Keywords: quality of life, children, hydrocephalus or brain neurovascular disorder, shunt

\section{Research Background}

Hydrocephalus is a condition that often occurs in children, whereas there is the accumulation of abnormal cerebrospinal fluid (CSF) in the brain cavities (ventricles) (Nordqvist, 2017; Rahmayani, Gunawan, \& Utomo, 2017b). Hydrocephalus occurs around 75,000 per year in US hospitals and more than $50 \%$ of hydrocephalus cases are congenital (NHF, 2018). The incidence of congenital hydrocephalus is around 68-316 cases per 100,000 births in America (Dewan et al., 2018). In Indonesia, the incidence of hydrocephalus in 2013 was around 14,21618,955 (Agung, 2016). The increased intraventricular pressure and ventriculomegaly are due to hydrocephalus which contributes to neurovascular damage and inflammation. The damage and inflammation of neurovascular causes injury to brain tissue resulting in impaired brain development (Kahle, Kulkarni, Jr, \& Warf, 2016).

Impaired brain development dealt impacts children's ability which is characterized by a decrease in intellectual capacity, motor deficits, and behavioral difficulties and can

\footnotetext{
* Corresponding author: Deni Lusiana

bernadetha.deni@gmail.com

Published online at http://IJDS.ub.ac.id/

Copyright (C) 2020PSLD UB Publishing. All Rights Reserved
}

affect their quality of life from childhood to adulthood (Rahmayani, Gunawan, \& Utomo, 2017a). The disorder also results in epilepsy and even death in children due to untreated hydrocephalus (Tully, 2015; Wong, 2009). A shunt implant is a surgical procedure to treat hydrocephalus. However, the implant is not free from the problem of a blockage in the shunt which can trigger seizures and infections. (Bawa, Sundaram, Dash, Peters, \& Rao, 2017; Smith, Cheater, \& Bekker, 2015).

Shunt implants indirectly impact the cognitive, social, emotional and physical deficits which affect the quality of individual health (Bawa et al., 2017). The argument is supported by results of research by Priyanka, et al (2018) that children who undergo Shunt implant surgery due to hydrocephalus, experience headaches and fatigue which affected their functional status disorders. Children also experience blurred vision, speaking difficulty, diplopia, fever, and seizures which affected the children's academic achievement related to cognitive and socialemotional aspects, and thereby affecting the quality of life in children. Children with hydrocephalus who have the various quality of life problems, in the long run, the problems will cause children to experience depression, unable to live independently, unpermitted to 
have a driver's license, unemployment, drug abuse, and refusal to get health insurance (Kulkarni, 2010). Based on this, children with hydrocephalus attached to the shunt need optimal care (Oktaviani, Anggraeni, \& Kusumaningsih, 2017). The treatment can improve the quality of life, so an evaluation of the quality of life of children with hydrocephalus is needed by using standardized instruments and it is very important in caring for children with hydrocephalus with a shunt to be able to face life challenges faced (Gürol, Erdem, \& Taşbaşi, 2015). Therefore, the writers are interested in conducting a literature review study related to the effective instruments for evaluating the quality of life of hydrocephalus children with shunt implants

\section{Method}

\subsection{Data search}

Search for articles carried out systematically to extract data. We used step by step for assessing the quality of research articles. The article searching method utilizes several electronic databases, namely Scopus, Proquest, PubMed and CINAHL with the keywords quality of life, child * or pediatric, hydrocephalus or of the brain neurovascular disorders, shunt.

\subsection{Inclusion and Exclusion Criteria}

The inclusion criteria are (1) research articles which titles and contents are by the objectives of the study, (2) full text, (3) written in English, (4) published in 2015-2019. On the other hand, the exclusion criteria are: (1) articles of which structure are incomplete, (2) the said articles are in the form of article review.

\subsection{Extraction Data}

Articles obtained from database searches are Scopus 209 articles, Proquest 2548 articles, PubMed 71 articles, and CINAHL 57,942 articles. Total articles obtained from four databases were collected 60,770 articles, then filtered with the assessment of research in the last five years and discussed the quality of life of children with hydrocephalus so that 358 articles were obtained. The same article was issued with a total of six articles. The article was reviewed with the criteria of accepting an assessment of the quality of life of children with the installation of a shunt obtained by 339 articles. A total of 13 articles, then 3 articles were excluded because of qualitative research methods so that the total of the final articles completed ten articles.

\section{Result and Discussion \\ 3.1. Types of Questionnaires to Evaluate Quality of Life}

This literature study is conducted on 10 articles discussing the instruments to evaluate the quality of life of children with hydrocephalus with shunt implants; the instruments include the HOQ, OHS, PedsQL 4.0, HQOL, mRS and SLHS questionnaires.

\subsubsection{Hydrocephalus Outcome Questionnaire (HOQ)}

The questionnaire-based on the HOQ (hydrocephalus outcome questionnaire) uses 53 items to assess the children's quality of life (15 items for the physical domain, 25 items for the social-emotional domain, 13 items for the cognitive domain) from Kulkarni 2004 (Iglesias, Ros, \& Martín, 2018; Karmur \& Kulkarni, 2017; Prakash et al., 2018). This questionnaire is used in children with age in the range of 4-18 years; and the number of males is more than female except in the research (Karmur \& Kulkarni, (2017) with a difference of $1 \%$. HOQ questionnaires also incorporate HUI questionnaires used for assessing vision, hearing, speech, cognitive, emotion, pain, ambulation and dexterity by combining the HOQ questionnaires (Karmur \& Kulkarni, 2017).

\subsubsection{Overall Health Score (OHS)}

OHS is another questionnaire to assess the quality of life of hydrocephalus children with shunt implants in the physical, socialemotional and cognitive domains by combining PCS questionnaires obtained from parents or caregivers that contain about the child's ability to take care of their family in the future, get a job, live alone in the future, the need for future shunt surgery, children's education, children's ability to socialize, children's ability to participate in sports, shunts that are not functioning and are infected. This questionnaire is also used in children aged 4-17 years (Bawa, Sundaram, Dash, Peters, \& Rao, 2019).

\subsubsection{Pediatric Quality of Life Inventory (PedsQL 4.0.)}


PedsQL 4.0 from Varni is a questionnaire to assess the quality of life of hydrocephalus children which includes physical function, emotional function, social function and school function (Eloqayli \& Alyousef, 2019; Gigi, Roth, Eshel, Constantini, \& Bassan, 2019; Mikkelsen et al., 2017; Zahl, Egge, Helseth, Skarbø, \& Wester, 2018). This questionnaire was used in children with the age of 13-48 months; and the number of males is more than the number of females (Eloqayli \& Alyousef, 2019), 2-8 years old (Gigi et al., 2019), 8-18 years old (Mikkelsen et al., 2016; Zahl et al., 2018), in addition to repeated surgery of less than 50\% (Mikkelsen et al., 2016), besides, the Battelle developmental inventory 2nd edition instrument is also used by Gigi et al., (2019) by combining the PedsQL 4.0 instrument from Varni to evaluate cognitive, personal-social and adaptive skills in children with hydrocephalus and shunts.

\subsubsection{Health-related Quality of Life (HQOL)}

Short Form Health Survey (SF-36) is a questionnaire to assess $\mathrm{HQOL}$ in eight domains, namely physical, social function, limited role, emotional, pain, mental health, vitality, general health perception and using the Barthel Index (BI) to assess functional status (Paulsen et al., 2015). This questionnaire is used for children aged less than 14 years with a greater number of male respondents

\subsubsection{Modified Rankin Scale (mRS) and Stein and Langfitt Hydrocephalus Score (SLHS)}

Modified Rankin Scale (mRS) assesses disability disorders; and Stein and Langfitt Hydrocephalus Score (SLHS) assesses gait, incontinence, and dementia in addition to hydrocephalus children with cerebral palsy using Gross Motor Function Classification System (GMFCS) and Manual Ability Classification System (MACS) which is a classification system for determining the level of gross motor function and the level of manual ability. This questionnaire is used for individuals aged $25-41$ years and assesses the previous function; and the number of male respondents is more than female (Preuss et al., 2014).

\section{Discussion}

According to the World Health Organization (WHO), quality of life is an individual's perception of life by their goals, expectations, standards, and concentrations. Quality of life can be reflected in physical, social-emotional and cognitive well-being. Children with hydrocephalus with shunt implants are impacted on their physical, socialemotional and cognitive quality of life (Eloqayli \& Alyousef, 2019), therefore, standard instruments are needed to measure physical, social-emotional and cognitive (Gigi et al., 2019).

From the article searching, ten articles in the form of a questionnaire were obtained about the standard instrument used to measure the quality of life of hydrocephalus children with shunt implants. From the articles, five types of questionnaires were found. The questionnaires in the article include the Hydrocephalus Outcome Questionnaire (HOQ) questionnaires used in three articles, the Pediatric Quality of Life Inventory (PedsQL) questionnaires used in four articles, one article used the Overall Health Score (OHS) questionnaire, another article used the Health-related Quality of Life (HRQOL), and one article used the Modified Rankin Scale (mRS) and Stein and Langfitt Hydrocephalus Score (SLHS). In general, the questionnaires have been tested for validity. Each questionnaire measures the quality of life of children from the physical, social-emotional and cognitive domains.

The research articles utilizing the HOQ questionnaire consist of 51 question items with three domains declared valid to measure the quality of life of hydrocephalus children with shunt implants. The three domains, namely the 15 items measuring physical condition, 25 items on socio-emotional and 13 cognitive items. Another article states that HOQ has been tested for validity and reliability by the Division of Neurosurgery at Toronsos Hospital and the reliability result is 0.70 . Some of these studies were conducted on hydrocephalus children aged 4-18 years. Most respondents in the study using the questionnaire were 158 children with hydrocephalus. From the four articles which utilize the questionnaires, mentioned that HOQ has been proven to be valid, reliable and simple to measure the quality of life hydrocephalus children with shunt implants (Iglesias et al., 2018; Karmur \& 
Kulkarni, 2017; Prakash et al., 2018; Preuss et al., 2014).

Another questionnaire utilized to measure the quality of life hydrocephalus children with shunt implants is PedsQL. The questionnaire consisted of 21 items with 4 domains namely physical, emotional, social and school functions. Some studies utilize the questionnaire on respondents with the age range from 2-18 years. The validity test results from one of the articles reveal an adequate and satisfying validity (0.77-0.88). Most respondents to measure the quality of life with shunt implanted hydrocephalus are 176 respondents (Eloqayli \& Alyousef, 2019; Gigi et al., 2019; Mikkelsen et al., 2017; Zahl et al., 2018).

One article that measures the quality of life of hydrocephalus children with shunt implants is using the OHS questionnaire. OHS questionnaire has 15 items that are related to physical conditions, 24 items on socialemotional, and 12 items on the cognitive section. The total OHS questions include 51 items which were divided into 3 domains, but the study states that the questionnaire has not been proven to be valid for the control group (Bawa et al., 2019). Another questionnaire from a study used to measure the quality of life is HRQOL. The questionnaire consists of 36 items divided into eight domains namely physical, social, emotional, mental, vitality, health perception, limited role, and pain. The article which utilizes HRQOL states that in the social domain, the questionnaire turns out to be less valid in measuring the quality of life of hydrocephalus children (Paulsen, Lundar, \& Lindegaard, 2015b).

The Modified Rankin Scale (mRS) and Stein and Langfitt Hydrocephalus Score (SLHS) questionnaire is also utilized to measure the quality of life hydrocephalus children with VP-shunts implanted. The results of the mRS and SLHS do not correlate with social, educational or overall outcomes, but with a poor condition namely epilepsy. The obtained result correlated with school levels that are socially and professionally related; In other words, this questionnaire still lacks in measuring the quality of life hydrocephalus children with shunt implants on decent conditions (Preuss et al., 2014).

\section{Conclusion}

Based on the findings of the reviewed ten articles, measuring the quality of life of hydrocephalus children can be done by utilizing many instruments that are already standardized. The instruments to evaluate the quality of life of hydrocephalus children with shunt implants are the HOQ, OHS, PedsQL 4.0, HQOL, mRS and SLHS questionnaires. The results of measuring the quality of life of children with hydrocephalus attached to the shunt become the basis in providing and developing interventions to improve the quality of life of hydrocephalus children with shunt implants.

Some questionnaires that are widely used are PedsQL questionnaire and HOQ which have been valid for use as instruments. The two questionnaires can be adapted as an instrument to evaluate the quality of life of hydrocephalus children with shunt implants.

\section{References}

Agung. (2016). INA shunt solusi bagi penderita hidrosefalus. 955(September 2009), 1. Retrieved from https://ugm.ac.id/id/berita/12249-

ina.shunt.solusi.bagi.penderita.hidrosef alus

Bawa, M., Sundaram, J., Dash, V., Peters, N. J., \& Rao, K. L. N. (2017). Healthrelated quality of life in children with congenital hydrocephalus and the parental concern: An analysis in a developing nation. Journal of Pediatric Neurosciences, 12(3), 255-258. https://doi.org/10.4103/jpn.JPN_42_17

Bawa, M., Sundaram, J., Dash, V., Peters, N. J., \& Rao, K. L. N. (2019). Health-related quality of life in children with congenital hydrocephalus and the parental concern: An analysis in a developing nation. 2017-2020. https://doi.org/10.4103/jpn.JPN

Dewan, M. C., Rattani, A., Mekary, R., Glancz, L. J., Yunusa, I., Baticulon, R. E., ... Warf, B. C. (2018). Global hydrocephalus epidemiology and incidence: Systematic review and metaanalysis. Journal of Neurosurgery JNS, 130(4), 1065-1079. https://doi.org/10.3171/2017.10.JNS174 
39

Eloqayli, H., \& Alyousef, A. (2019). Infantile hydrocephalus: Health-related quality of life outcome following abstract. 5054.

https://doi.org/10.2174/1874205X0191 3010050

Gigi, M., Roth, J., Eshel, R., Constantini, S., \& Bassan, H. (2019). Health-related quality of life after post-haemorrhagic hydrocephalus in children born preterm. Developmental Medicine and Child Neurology, 61(3), 343-349. https://doi.org/10.1111/dmen.14012

Gürol, A., Erdem, Y., \& Taşbaşi, F. . (2015). The experienced problems of mothers having children with hydrocephalus: A qualitative study. International Journal of Caring Sciences, 8(2), 435-442.

Iglesias, S., Ros, B., \& Martín, Á. (2018). Functional outcome in pediatric hydrocephalus: Results of applying the spanish version of the hydrocephalus outcome questionnaire. https://doi.org/10.3171/2017.8.PEDS16 700 .

Kahle, K. T., Kulkarni, A. V, Jr, D. D. L., \& Warf, B. C. (2016). Hydrocephalus in children. The Lancet, 387(10020), 788799. https://doi.org/10.1016/S01406736(15)60694-8

Karmur, B. S., \& Kulkarni, A. V. (2017). Medical and socioeconomic predictors of quality of life in myelomeningocele patients with shunted hydrocephalus.

Kulkarni, A. V. (2010). Quality of life in childhood hydrocephalus: A review. Child's Nervous System, 26(6), 737743. https://doi.org/10.1007/s00381010-1131-0

Mikkelsen, R., Rødevand, L. N., Wiig, U. S., Zahl, S. M., Berntsen, T., Skarbø, A. B., ... Wester, K. (2017). Neurocognitive and psychosocial function in children with benign external hydrocephalus (BEH) - a long-term follow-up study. Child's Nervous System, 33(1), 91-99. https://doi.org/10.1007/s00381-0163267-z

Mikkelsen, R., Rødevand, L. N., Wiig, U. S.,
Zahl, S. M., Berntsen, T., Skarbø, A., \& Egge, A. (2016). Neurocognitive and psychosocial function in children with benign external hydrocephalus ( BEH ) - a long-term follow-up study. Child's Nervous System. https://doi.org/10.1007/s00381-0163267-z

NHF. (2018). Facts about hydrocephalus. Retrieved from https://nhfonline.org/facts-abouthydrocephalus/

Nordqvist, C. (2017). "What is hydrocephalus, or water on the brain?" Medical news today. https://www.medicalnewstoday.com/art icles/181727.php.

Oktaviani, M., Anggraeni, L. D., \& Kusumaningsih, C. I. (2017). Pengalaman orangtua yang memiliki anak dengan hidrosefalus. Jurnal Persatuan Perawat Nasional Indonesia (JPPNI), $\quad 1(2), \quad 137$. https://doi.org/10.32419/jppni.v1i2.22

Paulsen, A. H., Lundar, T., \& Lindegaard, K. F. (2015a). Pediatric hydrocephalus: 40year outcomes in 128 hydrocephalic patients treated with shunts during childhood. Assessment of surgical outcome, work participation, and healthrelated quality of life. Journal of Neurosurgery: Pediatrics, 16(6), 633641. https://doi.org/10.3171/2015.5.PEDS14 532

Paulsen, A. H., Lundar, T., \& Lindegaard, K. F. (2015b). Pediatric hydrocephalus: 40year outcomes in 128 hydrocephalic patients treated with shunts during childhood. Assessment of surgical outcome, work participation, and healthrelated quality of life. Journal of Neurosurgery: Pediatrics, 16(6), 633641. https://doi.org/10.3171/2015.5.PEDS14 532

Prakash, P., Dhandapani, M., Ghai, S., Singh, N. V., \& Dhandapani, S. (2018). Quality of life among children who had undergone ventriculoperitoneal shunt surgery. Journal of Pediatric Neurosciences, 189-195. 
https://doi.org/10.4103/jpn.JPN

Preuss, M., Kutsher, A., R.Wachowiak, AMerkenschlager, M.K.Bernhard, \& M.Reis. (2014). Adult long-term outcome of patients after congenital hydrocephalus shunt therapy. https://doi.org/10.1007/s00381-0142571-8

Rahmayani, D. D., Gunawan, P. I., \& Utomo, B. (2017a). Profil klinis dan faktor risiko hidrosefalus komunikans dan non komunikans pada anak di RSUD dr. Soetomo. Sari Pediatri, 19(1), 25. https://doi.org/10.14238/sp19.1.2017.25 $-31$

Rahmayani, D. D., Gunawan, P. I., \& Utomo, B. (2017b). Profil klinis dan faktor risiko hidrosefalus komunikans dan non Komunikans pada anak di RSUD dr. Soetomo. Sari Pediatri, 19(1), 25. https://doi.org/10.14238/sp19.1.2017.25 $-31$

Smith, J., Cheater, F., \& Bekker, H. (2015). Parents' experiences of living with a child with hydrocephalus: A crosssectional interview-based study. Health Expectations, 18(5), 1709-1720. https://doi.org/10.1111/hex.12164

Tully, H. M. (2015). Clinical and surgical factorc associated with increased epilepsy risk in children with hydrocephalus. Pediatric Neurology. https://doi.org/DOI:

10.1016/j.pediatrneurol.2016.02.011

Wong, D. (2009). Buku ajar keperawatan pediatric edisi 6 . St Louis, US: Mosby Yearbook Inc Us.

Zahl, S. M., Egge, A., Helseth, E., Skarbø, A., \& Wester, K. (2018). Quality of life and physician-reported developmental , cognitive, and social problems in children with benign external hydrocephalus - long-term follow-up. https://doi.org/https://doi.org/10.1007/s 00381-018-4016-2 